\title{
CONSTITUTION \& RULES OF THE NEW ZEALAND SOCIETY FOR EARTHQUAKE ENGINEERING INCORPORATED
}

\section{NAME}

1.1. The Society shall be named, "The New Zealand Society for Earthquake Engineering Incorporated", (hereinafter referred to as "the Society".)

\section{OBJECTS}

2.1. The objects of the Society shall be to:

a) Foster the advancement of the science and practice of earthquake engineering.

b) Retain a close liaison with the Institution of Professional Engineers of New Zealand Incorporated by being a technical group of the Institution and

c) Further the objects of the International Association for Earthquake Engineering as applicable to New Zealand viz:

"to promote international cooperation among scientists, engineers and other professionals in the broad field of earthquake engineering through interchange of knowledge, ideas, results of research and practical experience."

2.2. The Society is established to do all such things as are conducive or incidental to attaining the aforesaid objects or any of them.

\section{QUALIFICATION FOR MEMBERSHIP}

3.1. Membership of the Society shall comprise professional engineers, scientists and others having an interest in earthquake phenomena or in the effects of earthquakes.

3.2 On admittance to membership members shall conduct their affairs ethically and do nothing to bring the Society into disrepute.

\section{APPLICATION FOR AND ELECTION TO MEMBERSHIP}

4.1. Admission to membership of the Society shall be subject to the approval of the Management Committee.

4.2. Ordinary Membership: Ordinary members shall be individuals who fulfil the qualifications for membership.. Applications for ordinary membership shall be made on a form provided by the Society. Applicants shall supply details of their occupation, academic qualifications, experience and field of interest in earthquake engineering or related matters as the Management Committee shall decide.
4.3. Corporate Members: A Corporate member shall be a body corporate or other firm or organisation not being a body corporate interested in furthering the science and practice of earthquake engineering, and the maintaining of a high professional standard in all branches of earthquake engineering research and practice.

Applications for Corporate membership of the Society may be made by companies or bodies corporate on the Corporate Membership Application Form provided by the Society. Such applicants shall supply contact details, and outline of the extent of their interests in earthquakes, and shall designate a nominee to represent them in Society matters. The designated nominee of each Corporate member shall enjoy the privileges of an ordinary member. When a vote is taken, Corporate members are entitled to one vote, which is to be cast by the nominee.

4.4. Life Members: The Management Committee may elect as a "Life Member" any person, whether resident in New Zealand or otherwise, who has made an extraordinary contribution to earthquake engineering in New Zealand or elsewhere. A person so elected shall have full membership rights of the Society, but shall not be required to pay any membership subscription.

4.5. Fellows: The Management Committee may elect as a Fellow of the Society any person, whether resident in New Zealand or otherwise who, in the Committee's estimation, fulfils all of the following requirements:

a) the nominee must have been a member of the Society for at least five years immediately prior to nomination; and

b) the nominee must be highly respected in some aspect of the fields of earthquake engineering, earthquake phenomena or the effects of earthquakes; and

c) the nominee must have performed exceptional service to the Society as demonstrated by:

- work on the Management Committee; and/or

- work on one or more of the Society's Bulletins; and/or

- publication in the Society's Bulletin; and/or

- other special contribution which benefits the Society.

Prospective Fellows shall be nominated by three current members of the Society, who shall submit with their nomination a brief statement supporting the nominee's case for election. 
In the event of an initially unsuccessful nomination, the nomination shall stand for three years subsequent to nomination and if not by then successful, shall lapse. Renomination of an unsuccessful candidate will not be accepted for the three years subsequent to failure of a previous nomination.

NOTE: Normally not more than five percent of the Society's membership shall be Fellows at any one time. The Management Committee will biennially publish a call for nominations and the closing date for nominations.

\section{RESIGNATION, MEMBERSHIP FORFEITURE AND RE-ADMISSION}

5.1. Each member may, by notice in writing to the Society, resign his or her membership after payment of all sums due from him or her in respect of subscriptions or otherwise.

5.2. Any member who is adjudicated bankrupt, or who makes a compromise with his or her creditors, or who is convicted of a criminal offence, or who is of unsound mind, shall immediately have his or her membership terminated.

5.3. Any member infringing any Rule or regulation or misconducting himself or herself shall be answerable to the Management Committee who may at their discretion suspend such a member or may by a majority of not less than three (3) votes, terminate his or her membership.

5.4. If the subscription of a member remains unpaid for $\mathbf{1 2}$ months, membership of the Society shall be forfeited.

5.5. Each person who has ceased to be a member for any reason may apply for re admission and the Management Committee may approve such readmission under such conditions as it may see fit to impose.

\section{MANAGEMENT OF THE SOCIETY}

6.1. The affairs of the Society shall be managed by a committee of a minimum of 9 persons to be known as the Management Committee of the N. Z. Society for Earthquake Engineering Incorporated (herein referred to as the "Management Committee").

6.2. Society members shall annually elect nine of their number to the Management Committee as provided for in Rule 6.8. The Bulletin Editor for the Society and the immediate past President of the Society in the year following his or her relinquishing the office of President shall be members of the Management Committee. The Earthquake Commission shall have the right in its discretion to appoint one person to the Management Committee.

6.3 The Management Committee shall appoint from their number the President of the Society, who shall also be Chairperson of the Management Committee. No person shall hold the office of President for more than two consecutive years.

6.4. Each elected member of the Management Committee shall serve for one year. He or she may be re-elected or reappointed but for not more than six consecutive years.
6.5. The Management Committee may fill a casual vacancy including a vacancy not filled at an election.

6.6. The Management Committee shall appoint the Secretary of the Society whose duties shall include keeping minutes of meetings of the Society and the Management Committee.

6.7. Candidates may offer themselves for election to the Management Committee in any one, but not more than one, of the following categories

Category 1: Geologist

Category 2: Geophysicist or Seismologist

Category 3: Research scientist concerned with problems in, or related to, earthquake engineering

Category 4: Architect

Category 5: Ordinary member

The qualification of a candidate for election in any of the Categories 1 to 4 inclusive ( the special categories ) shall be accepted if the candidate is actively engaged principally in the discipline defined by the category in the course of his or her normal work. A candidate qualified for election in any of the Categories 1 to 4 may seek election as an Ordinary Member; but shall not, in that event, be accepted as a candidate for the special category.

Nominations shall be on forms supplied by the Secretary, shall show the category for which the candidate seeks election, shall be signed by the candidate, his or her proposer and seconder, all of whom shall be financial members of the Society, and shall reach the Secretary not later than two calendar months before the date of Annual General Meeting.

6.8. The election of members of the Management Committee shall be by postal ballot and shall be in categories of membership as defined in Rule 6.7. Every member of the Society may vote for one candidate in each of Categories 1 to 4 inclusive and 5 candidates in Category 5. Ballot papers together with brief biographical notes about candidates shall be posted to all members not later than 21 days before the date of the Annual General Meeting.

6.9. At its discretion the Management Committee may co-opt additional members to serve for all or part of an annual term. The criteria for co-option shall be the expertise or involvement in an activity to be undertaken under the auspices of the Management Committee and where the Management Committee feels that such expertise could assist in the success of the activity or project. Co-opted members shall have full speaking rights, but not voting rights at Management Committee meetings.

\section{POWERS AND DUTIES OF THE MANAGEMENT COMMITTEE}

7.1. The Management Committee shall be responsible to the members of the Society for the policy and administration of the Society and its powers shall include: 
a) Publication of information, technical or nontechnical, about earthquake engineering.

b) Establishment and maintenance of direct communication and liaison with International Association for Earthquake Engineering, with the Institution of Professional Engineers New Zealand and with any other organisation with objects similar to those of the Society.

c) Communication with and representation to any authority responsible for legislation, for regulations or for issuing advisory or mandatory rules of any description which are or which should be affected by earthquake considerations, including the right to make public statements about questions concerned with earthquake engineering and related matters.

d) Arrangement of conferences, seminars and symposia.

e) Formation of branches and specialist groups.

f) Establishment and maintenance of technical libraries and information services.

g) Initiation and maintenance of or support for research in earthquake engineering and related fields.

h) Management of the financial affairs of the Society, including determination of the annual membership subscription rate, the control and investment of the Society's funds, and the opening and operating of such bank account or accounts as may be deemed necessary for the purposes of the Society.

i) The appointment of necessary staff and the determination of their remuneration.

j) Determination of applications for membership, including election of Life Members (see 4.4) and Fellows (see 4.5).

k) The power to build, purchase, lease, rent, hold and/or furnish any building or premises for the use of the Society and its members and may from time to time dispose of some or any part of it.

1) The power to make and give receipts, rebates and other discharges of monies payable to the Society and for the claims and demands of the Society.

m) The power to invest and deal with any money of the Society upon such security and in such manner as it thinks fit, and from time to time vary such investments.

n) The power to borrow or otherwise raise money in such manner as it thinks fit and to secure repayment by the issue of debentures or by mortgages or charges upon the whole or part of the property and assets of the Society (whether present or future) and to purchase, redeem or pay off any such securities.

7.2. The Management Committee shall meet as often as the business of the Society may require, but not less frequently than four times annually, and shall keep minutes of all meetings.
7.3 At meetings of the Management Committee the quorum shall be 5 members.

7.4. Decisions of the Management Committee on the Interpretation of the Rules of the Society on all matters dealt with in accordance with such Rules and on matters not provided for in such Rules shall be final and binding on all members of the Society.

7.5. The Management Committee shall prepare an Annual Report which shall be circulated by the Secretary to each member of the Society to reach him or her not less than 14 days before the Annual General Meeting and shall be laid before, and adopted or otherwise, by such meeting.

\section{FINANCE}

8.1 The annual subscription payable by members shall be fixed by the Management Committee from time to time

8.2. The financial and subscription years shall commence in any year on 1 October and end on 30 September of the following year.

8.3. Each member of the Society except life members shall pay the annual subscription. The annual subscription shall be due on 1 October in each year of membership.

8.4. Any member whose annual subscription remains unpaid for 5 calendar months after becoming due shall be regarded as 'in arrears of subscription'. The Secretary shall write to such persons advising them of the situation and requesting immediate payment. If the subscription remains unpaid one month after receipt of the Secretary's letter, all rights of membership shall be suspended until the subscription arrears have been paid, and membership of the Society shall be forfeited in accordance with 5.4.

8.5 The Society shall keep proper books of account.

8.6 All monies received on account of the Society shall be paid into the account of the Society with its Bankers and shall be acknowledged by an officer or a paid employee of the Society. All cheques drawn upon the Bankers of the Society shall be signed in such manner and by such persons as the Management Committee shall from time to time determine. Cheques or other negotiable instruments paid or payable to the Society's Bankers for collection requiring endorsement of the Society may be endorsed by such person or persons as the Management Committee shall from time to time appoint.

8.7. At the end of each financial year the Management Committee shall prepare an Annual Statement of Account which after being certified by the Auditors of the Society shall be circulated by the Secretary to each member of the Society to reach him or her not less than 14 days before the Annual General Meeting and shall be laid before, and adopted or otherwise, by such meeting.

8.8. The financial activities of the Society shall be limited to within New Zealand. The Management Committee may from time to time invest and re-invest in such securities and upon such terms as it shall think fit the whole or any part of the funds of the Society which shall not be required for the immediate business of the Society.

8.9 If at any time the Society in general meetings shall pass a resolution authorising the Management Committee to 
borrow money, the Management Committee shall be empowered to borrow for the purposes of the Society such amount of money either at one time or from time to time and at such rate of interest and in such form and manner and upon such security as shall be specified in such resolution and thereupon the Management Committee shall make all such dispositions of the Society property or any part thereof and enter into such agreements in relation to it as the Management Committee may deem proper or giving security for such loans and interest. All members of the Society whether voting on such resolution or not and all persons becoming members of the Society after the passing of such resolution shall be deemed to have assented to the same as if they had voted in favour of such resolution.

\section{ANNUAL GENERAL MEETING}

9.1. An Annual General Meeting of the Society shall be held once in each calendar year on such date and at such time and place as may be decided by the Management Committee, but not later than $30^{\text {th }}$ April in each year, for the following purposes:
(a) To receive the report of the President.
(b) To consider and receive the statement of accounts and duly audited balance sheet.
(c) To elect members of the Management Committee for the ensuing year.
(d) To decide on any resolution which may be duly submitted to the meeting.

9.2. Notice of each Annual General Meeting shall be circulated to each member to reach him or her not less than 14 days before such meeting.

9.3. The quorum for a Annual General Meeting shall be ten financial members.

\section{SPECIAL GENERAL MEETING}

10.1. The Management Committee may, whenever it thinks fit, call a Special General Meeting of the Society.

10.2 The Management Committee shall on the requisition of not less than ten financial members proceed to convene a Special General Meeting of the Society. The requisition must state the objects of the meeting and be signed by the requisitionists and deposited with a member of the Management Committee.

10.3 Notice of each Special General Meeting and details of the nature of the business to be transacted shall be circulated to each member to reach him or her not less than 14 days before such meetings.

10.4 The quorum for each Special General Meeting shall be ten financial members.

10.5 No business shall be transacted at a Special General Meeting other than that specified in the notice convening such meeting.

\section{VOTING BY MEMBERS}

11.1. Votes at an Annual or Special General Meeting may be given either personally or by proxy. Written notice of an appointed proxy shall be prepared and signed by the appointor. Proxies may only be assigned to financial members of the Society who are qualified to vote. The proxy shall only be exercised on matters for which due notice has been given. Proxies given by post may be accepted as valid if received by the Secretary by the date decided by the Management Committee and advised to members.

11.2. Each member not being a member disqualified under Clause 11.7 present either in person or by proxy shall have the right to exercise one vote only on each motion before such meeting except that in the case of equality of voting the Chairperson of the meeting may exercise a casting vote in addition to his/her deliberative vote.

11.3. Voting on any motion before such meeting shall subject to recognition of proxies be by voice except that any such member present at such meeting may require a show of hands and any ten per centum of such members present at such meeting may require a secret ballot; but at any meeting, and unless the Chairperson of the meeting is required by the meeting to advise the number of votes cast for and against the motion, a declaration by the Chairperson of the meeting that a resolution put to the meeting has been carried or lost and an entry recorded to that effect in the book of proceedings of the Society shall be conclusive evidence of the fact.

11.4. A majority of the votes at any such meeting shall decide any question.

11.5. All instruments appointing proxies shall be in writing under the hand of the appointor. The instrument shall be in a form authorised by the Management Committee.

11.6. The notice appointing a proxy shall be received by the Secretary not less than twenty four hours before the time of the holding of the meeting.

11.7. No member shall be entitled to be present or to vote on any question, either personally or by proxy or as proxy for another member at any meeting if he or she is "in arrears of subscription" as defined in Clause 8.3.

\section{COMPLIANCE WITH RULES OF THE SOCIETY}

12.1. Members of the Society shall be bound by the Rules of the Society and the form of application for membership shall contain a declaration in the following terms to be signed by each applicant:

"If admitted to Membership, I agree to abide by the rules of the New Zealand Society for Earthquake Engineering Incorporated."

\section{STANDING ORDERS FOR MEETINGS}

13.1. The Standing Orders of the Society shall be in accordance with the Standing Orders prescribed in Appendix A. 


\section{ALTERATION OF RULES}

14.1. Alteration, addition or rescission to the Rules of the Society shall be by a majority vote of a Special General Meeting of the Society.

14.2. The Management Committee shall within fourteen (14) days register any such alteration, addition or rescission with the Registrar of Incorporated Societies in accordance with Section 21 of the Incorporated Societies Act 1908.

No alteration, addition, rescission or substitution which would alter the charitable nature of the Society shall be permitted.

\section{LIQUIDATION}

15.1. The Society shall be liquidated and thus cease to continue to operate by decision of the members at a meeting convened for the purpose of considering such proposal. On that happening no member of the Society can participate in any financial surplus remaining and the whole of that surplus, less any professional costs incurred in effecting the winding up, shall be distributed for charitable purposes within New Zealand.

\section{COMMON SEAL}

16.1. The Society shall have a common seal, which shall be kept in the custody and control of the Secretary for the time being of the Society. The Society shall execute any document pursuant to a resolution of the Society passed for that purpose by affixing the common seal in the presence of two members of the Management Committee.

\section{APPENDIX 1}

\section{STANDING ORDERS FOR MEETINGS}

1.1. GENERAL
(a) Meetings of the Society shall be conducted in accordance with the following Standing Orders.
(b) Except as provided in the Rules these standing orders are not binding on meetings.

\subsection{CHAIRPERSON}

(a) At each Meeting the President shall take the chair.

(b) If the President is not present a meeting shall elect its own chairperson.

\subsection{MINUTES}

Minutes of each meeting shall be kept by the Secretary and at each meeting the minutes of the previous meeting of a like nature shall be submitted to the meeting for approval and then signed by the chairperson, before any other business is transacted.

\subsection{ORDER OF BUSINESS}

Except as provided herein the order in which business is transacted at each meeting shall be at the discretion of the chairperson.

\subsection{MOTIONS}

(a) Except with the permission of the chairperson each motion or amendment shall be in writing.

(b) Each motion or amendment not seconded shall lapse without discussion and shall not be recorded in the minutes except by the permission of the meeting.

(c) After each motion or amendment has been moved and seconded it shall not be withdrawn without the permission of the meeting.

(d) Except with the permission of the meeting no motion or amendment shall be proposed which in the opinion of the chairperson is the same in substance as any motion or amendment which during the same meeting has been resolved in the affirmative or negative.

(e) Where no specific procedure is laid down the chairperson shall refuse to accept a motion to rescind any resolution or other vote if he/she considers that insufficient notice has been given to members.

(f) Before putting each motion or amendment to the vote the chairperson shall clearly state such motion or amendment.

\subsection{AMENDMENTS}

(a) A motion may be amended by leaving out words; by leaving out certain words and substituting other words; by inserting words; or by adding words.

(b) Each amendment shall be relevant to the original motion.

(c) No amendment may be accepted which produces a direct negative of the motion.

(d) Amendments to a motion may be moved without notice.

(e) Amendments may be moved in any order considered satisfactory by the chairperson.

(f) When an amendment has been carried, such amendment shall become the substantive motion, and shall be open to amendment accordingly.

(g) At the discretion of the chairperson amendments to an amendment shall be allowed.

\subsection{DEBATE}

(a) Except with the permission of the chairperson each member shall rise to speak, and shall speak only upon or to introduce a motion or amendment or upon a question of order, but not otherwise.

(b) If the chairperson rises a member speaking shall sit and no member shall rise or attempt to speak until the chairperson sits.

(c) All remarks shall be addressed to the chairperson. 
(d) Except with the permission of the chairperson no member may speak twice to a question before a meeting except:

(i) In explanation of some material point on which he/she claims to have been misunderstood, but he/she shall not introduce any fresh matter.

(ii) That unless otherwise provided a reply shall be allowed to a member who has moved a substantive motion, but not to a member who has moved an amendment. No fresh matter may be introduced during such reply.

(iii) To move an amendment.

(e) The chairperson may at his/her discretion at any stage of the meeting impose a time limit on speakers, whether generally or on the speakers to any particular motion or amendment then before the meeting.

(f) A debate may be interrupted at any time by a question of order; by want of a quorum, or by any of the formal motions noted in Clause 9, or by a motion for the reading of a document relevant to the motion or amendment.

\subsection{VOTING}

(a) Voting at meetings shall be conducted in accordance with Section 11 of the Rules. These Rules may not be suspended or varied.

(b) When a secret ballot is necessary scrutineers for such ballot shall be elected by the meeting.

\subsection{FORMAL MOTIONS}

(a) The following formal motions may be moved at any time. The chairperson may refuse to accept any such motion except formal motion (v) if the chairperson considers it premature:

(i) "That the question be now put."

(ii) "That the meeting proceed to the next business."

(iii) "That the meeting do now adjourn."

(iv) "That the meeting do now adjourn to (place and time)."

(v) "That the question be not now put."

(b) A formal motion relating to a motion or amendment may not be moved or seconded by a person who has taken part in the debate on such motion or amendment.

(c) Formal motions (i), (ii) or (iii) when moved and seconded and accepted by the chairperson shall be immediately put without debate or amendment.

(d) If formal motion (i) is carried and the question before the meeting is a motion the mover of such motion may reply after which such motion shall be immediately put.

(e) When formal motion (iv) has been moved and seconded and accepted by the chairperson, the place and time only may be debated and amended. Discussion of the motion or amendment previously before the meeting shall be suspended while such formal motion is dealt with.

(f) Formal motion (v) may be moved only in connection with a substantive motion and not with an amendment. When such formal motion has been moved and seconded it shall be debated in conjunction with the substantive motion before the meeting. When the debate terminates the chairperson shall first put the formal motion. If such motion is carried the meeting shall proceed to the next business without voting on the substantive motion. If the formal motion is lost the debate on the substantive motion shall be put without further debate.

\subsection{POINTS OF ORDER AND PROCEDURE}

(a) A member may at any time rise and address the chairperson on a point of order, but shall confine remarks to the point of order raised and shall interrupt a speech only when such necessity arises.

(b) When any question of order or procedure shall arise it shall immediately be taken into consideration and decided by the chairperson and the matter under discussion shall be suspended until the decision of the chairperson has been given which decision shall not be open to discussion at that meeting.

(c) All questions of order or procedure not provided for in these standing orders shall be decided by the chairperson.

\subsection{ADJOURNMENT}

A meeting may be adjourned only by its own resolution except that the chairperson may adjourn a meeting on the occasion of disorder or disturbance and shall do so if there is fewer than a quorum present.

\subsection{COMMITTEE}

(a) A meeting may by a duly carried resolution resolve itself into committee.

(b) In committee each member may speak as often as he/she desires. The decisions arrived at in committee shall be submitted as substantive motions after the meeting has resumed.

\subsection{SUSPENSION OF STANDING ORDERS}

Any standing order may be suspended by the assent of not less than two-thirds of the members present. The voting rules may not be suspended or varied. 